Article

\title{
The Image of Guru Nanak in Dadu-Panthi Sources
}

\author{
Louis E. Fenech
}

Department of History, University of Northern Iowa, Cedar Falls, IA 50614, USA; lou.fenech@uni.edu

Received: 4 August 2020; Accepted: 28 September 2020; Published: 10 October 2020

\begin{abstract}
This essay examines the issue of Guru Nanak's inclusion in the mid-to-late seventeenthcentury devotional text prepared by the Dadu-panthi savant, Raghavdas, the Bhakt-māl or Garland of Devotees. This text follows by some decades the similarly titled Bhakt-māl of Nabha Das. However, while Nabha Das excludes Guru Nanak, Raghavdas' Bhakt-māl embraces him and includes a much more diverse seventeenth- and pre-seventeenth-century saintly clientele that was particular to both northern and southern India. The essay is one of the first to examine this text in Sikh studies and tease out the reasons which may have prompted Raghavdas to include Guru Nanak. In the process, it attempts to understand early non-Sikh bhakti views of the Sikh Gurus while also providing fresh looks at Sikh numbers in the late sixteenth and early seventeenth centuries and at the diverse and multi-ideological environment of northern India from the early 1600s onward. It also suggests Raghavadas' familiarity with the poetry of his near contemporary ideologue, the great Sikh scholar Bhai Gurdas Bhalla.
\end{abstract}

Keywords: Sikh; Guru Nanak; Raghavdas; Dadu; Kabir; Bhai Gurdas; Bhakt-māl; Nabhadas; Udasi

Nānak sūraj rūp bhūp sārai parakāse

Nanak's true form is that of the sun, the sovereign whose light is diffused throughout the entire world.

Bhakt-māl 342:2 (Nahta 1965, p. 175)

\section{Introduction}

On this, the 550th birth anniversary of the first Sikh Master, Guru Nanak (1469-1539 CE), it is fitting that we recognize and celebrate the centuries-constant Sikh commitment to the teachings of the son of Kalu Bedi and Mata Tripta, especially given the solid foundation for Sikhi or Sikhism that these teachings have constructed. This Sikh focus on the First Guru and his doctrines has provided both encouragement and solace to Sikhs and others in times both difficult and those less so.

Scholarship on the Sikh tradition over the last century has done a fine job of excavating the ground of these teachings. ${ }^{1}$ Such study has underscored the originality of the way that Guru Nanak refracted his cultural and intellectual inheritance through the lens of his own charismatic personality and understandings, transforming what were a relatively loose collection of ideas conveyed in poetry and song by some of his similarly minded contemporaries into lucid and systematic doctrines-doctrines which, in conjunction with the First Master's specific sādhāna or discipline of nām simran allowed one to achieve the knowledge that secured liberation from the cycle of existence. These principles eventually took on a communal form and were compiled and organized into Guru Arjan's masterpiece, the Adi Granth also known as the Guru Granth or Guru Granth Sahib. These studies on Sikh history and scripture have also demonstrated the effects of these, the first Guru's principles on the long progression

1 Such studies include (McLeod 1968; Grewal 1979) among others. 
of the Sikh Panth and the length to which these ideas had shaped Sikh scripture (McLeod 1968; Grewal 1979).

In detailing these developments contemporary Sikh scholarship has followed the lead set by even earlier Sikh authors dating back to the very mid sixteenth-century origins of the religious biographies of Guru Nanak, the janam-sākhīs (lit., 'birth-evidence'). It is worth noting that today's popular narratives of Guru Nanak's life are almost solely derived from janam-sakhi accounts. These first authors, too, in their devotion to the First Guru, attempted to provide a thorough exegesis of the First Master's ideas though in the context of his life narratives, and in the process of so doing have constructed a future-oriented community based on reverence for both the man and his message. Grounded on the stories within the janam-sakhis it is quite clear that the most meagre of connections to Guru Nanak was enough to obtain liberation: in one sākhi, for example, Guru Nanak's mere glance towards the smoke of a murderer's funeral pyre was enough for the latter to secure paradise (McLeod 1980b, pp. 201-3).

However, these very same earlier writers, as too those who came afterwards, have neglected acknowledging almost all sixteenth- to eighteenth-century material referencing Guru Nanak and Sikh teachings that was produced by those who embraced the First Master or were sympathetic towards his teachings, but did not identify as Sikh or Nanak-panthi. This disregard on the part of those Sikh authors is understandable for a number of reasons. First, the janam-sakhis are lovingly written hagiographies of Baba Nanak which attempt to do far more than merely convey the life of the First Guru. They endeavor to persuade others-non-Sikhs—as to the truth that Nanak manifested, simultaneously aiming to establish a relationship between Guru Nanak and those identifying as his Sikhs, to aid in understanding the First Master's teachings through anecdotes of Guru Nanak's life; through this, listeners and readers may themselves obtain liberation. In this way, the janam-sakhis serve a soteriological purpose (McLeod 1968; McLeod 1980a). Second, Sikh authors appear to have simply demonstrated no interest in this regard. After all, most of the frameworks through which they view Guru Nanak and his panth, although bearing certain features in common with those of both Hindu and Islamic traditions, are nevertheless uniquely Sikh if only for their focus on he whom they identify as the founder of their tradition, a man who 'defeats' all challengers, Sufi, Nath, and yogi alike, to demonstrate the superiority of his mat or doctrine (a telos to be sure). Third, the size of the Sikh community in its first 100 or so years of existence was quite small although growing - as many scholars have noted (for one, McLeod 1975) by, for example, pointing to the creation of pilgrimage centers such as Goindwal or bustling towns such as Amritsar and nearby Tarn Taran in the late sixteenth century, the latter two of which, in particular, had recognizable groups of those who were part of the growing Nanak-panth-but nevertheless, these numbers were relatively slight when compared to northern India's overall population. As such, Sikhs, non-Sikh writers, and Mughal officials in administrative centers of the empire for that matter may have only rarely crossed paths which would, in turn, have ensured that non-Sikh accounts of the First Guru and his doctrines were few. But few, of course, is not none.

The fact that such sources exist should elicit surprise for those of us in Sikh studies because, for the most part, they are simply never mentioned explicitly, in either contemporary literature or that of today. These quite early non-Sikh observations are, however, important. On the one hand, they add a fascinating dimension to the study of both early Sikh history and the motivations on the part of these non-Sikh authors behind excluding or including references to the Sikhs and their Gurus. On the other hand, the examination of these sources, which emerge from within a clearly mid-to-late seventeenth-century Vaishnava bhakti milieu, will also help us chart out a more accurate history of the context in which the Sikh tradition grew and thrived, ${ }^{2}$ the areas to which it travelled, and the groups with which it was in competition and to which it was responding. These implicit responses,

2 That is to say, a history that goes beyond simply demonstrating the Panth's multiple responses to the whims of the Mughal emperors and their administrations. 
furthermore, lay bare at least some of the motivations behind the creation of the more celebrated works of Sikh literature. For, while there are no explicit references to these bhakti texts in Sikh works, I will argue that, generally, there are implicit ones.

Indeed, Sikh writers would later encounter these sources and react to them, albeit tacitly, contesting both the exclusion of the Gurus in certain texts and the way that the Gurus were depicted in others. Sikh works such as the famous vārān of Bhai Gurdas (mid seventeenth century) and the Sikkhān $d \bar{\imath}$ Bhagat-māl of Bhai Mani Singh (mid eighteenth century)—which is also known as the Bhagat Ratnāvali-have these bhakti works in mind as they advocate, quite forcefully, on the behalf of a separate and unique Sikh identity. It is this unique identity that the Hindu works implicitly reject by circumscribing the Gurus within the redemptive sphere of bhakti, Vaishnava or otherwise.

This paper will endeavor to attend to these long-neglected works within Sikh studies and address the points noted above. We have already mentioned the question of Sikh numbers, and will expand upon those references in part two of this essay, which concludes with a short discussion of the languages in which early non-Sikh accounts of the Sikhs were presented. All this to suggest the reasons why, firstly, the Sikhs were not generally noticed by non-Sikhs such as Nabhadas and secondly, why these few non-Sikh texts like that of Raghavdas were ignored by Sikhs. The third section will introduce more generally the textual source whose analysis forms the bulk of this paper, the Bhakt-māl of the Dadupanthi Bhakt, Raghavdas, with a rather extended discussion of this text's dating for reasons which will become obvious in part three. Sections four to six will focus on the specific chhappais or poems in which Guru Nanak is mentioned and situate these within the mid-to-late seventeenth-century literary context in which Raghavdas is writing, suggesting the Sikh sources that Raghavdas is engaging, whose views he is attempting to circumvent in his portrayal of Guru Nanak and the Sikhs. I will end with a brief afterword.

\section{Engagement: A Question of Numbers and Languages}

The existence at this time of a relatively limited number of Sikhs may help explain a few of the conundrums which emerge from surveys of early Sikh tradition and history. Some of these include the earliest interactions between Sikhs and Mughal administrators. Such small numbers, for example, explain why the famous chronicler of the emperor Akbar (r. 1556-1605 CE) the 'worldly' (Ällamî) Abul Fazl who does mention the emperor's visit to Guru Arjan in 1598 as the emperor is returning to Agra from Lahore, says nothing about the first Master (or his successors) and his teachings in his Ain-i Akbāri (Blochmann 1997). This text is a compendium that Abul Fazl prepared of the more well-known South Asian religio-cultural traditions (among other things) as seen and understood from the perspective of the late sixteenth-century Mughal court (Singh 1949, p. 19; Grewal and Habib 2001, p. 55). This lack is especially telling since the esteemed son of Shaikh Mubarak both includes so many contemporary non-Muslim traditions in what is surely his tour de force and, perhaps more importantly, even met the Guru of the Sikhs-and, as an aside, such an omission compels one to ask whether certain traditions claiming that Bhai Gurdas Bhalla (of whom more later) may have been present within the emperor's Ibādat-khānah (House of Worship) in Fatehpur Sikri are unfounded as a consequence (Singh 2006, p. 68). $\mathrm{Abu} 1$ Fazl's failure should not indicate that the ignorance of the Sikhs was widespread though as there is a singular mention of the community in various iterations of the Razm-nāmah, the Persian interpretation of the Sanskrit Mahabharata of Vyasa which was prepared for Akbar (Truschke 2016, p. 112).

The situation is not much changed a near decade later by the time of Guru Arjan's execution in 1606 under the orders of Akbar's son and successor the emperor Jahangir. Regarding the Sikhs, the only comments we discover in Mughal sources are found in the emperor's memoir, the Jahāngìr-nāmah. Jahangir describes Guru Arjan as a Hindu and make us privy to the fact that Guru Arjan's was a religious tradition which originated in India, had attracted both Hindus and Muslims, been growing for some generations-although the extent of its growth is left unsaid-and that it differed from that variety of Islam to which the emperor subscribed (Thackston 1999, p. 59). Mughal poets who wrote 
within the darbārs of both Jahangir and Shah Jahan, moreover, also failed to name the Sikhs in the occasional poem in which various social groups within the empire were identified. The poet laureate of Shah Jahan, for example, Abu Talib Kalim (d. 1651 CE) did not include the Sikhs in his encomium lauding the virtues of the city of Agra (Sharma 2017, pp. 116-17).

The Panth's slight numbers at this time may have played a part in the neglect shown towards Guru Nanak and his teachings by those earliest of non-Sikh hagiographers of the Bhakts (Hindi)/Bhagats (Punjabi), the saints of the Vaishnava tradition. This would include the pioneering Bhakt writer Nabhadas whose Bhakt-māl or Garland of Saints is the first of what will afterwards become a very popular seventeenth- and eighteenth-century genre, mimicked to an extent by later Sikh authors such as, apparently, the famous Bhai Mani Singh to whom is attributed the somewhat similarly titled Sikhān dī Bhagat-māl (Garland of Sikh Saints), which augments the well-known eleventh vār of Bhai Gurdas dedicated to the earliest followers of the Sikh Gurus, all of whom, for the author, stood spiritually above the best of Hindu Bhakts (Jha 1978).

The devotional flowers strung together on these garlands were highly condensed narratives of the Sants and Bhagats ${ }^{3}$ which formed aides de mémoire and were constructed in part to form a new public, a bhakti public (Williams 2014), and were also likely used by pious listeners in conjunction with their own gurus who would explain the pithy stories in detail to their audience, likely as katha (Pinch 1999, pp. 371-72; Horstmann 2015, p. 37). Nabhadas, as has been well documented (Hare 2011; Burchett 2012), fails to include Guru Nanak in his prodigious list of Bhakts. Additionally-although scholars have claimed that Nabhadas may have chosen to purposefully omit Guru Nanak and the Nanak Panth because of competition for patronage, or for the fact that Guru Nanak most often spoke of the nrgun divine, a deity beyond all qualities, while Nabhadas advocated on behalf of a variety of Vaishnavism which privileged the sagun (also trigun) or qualified divine (Burchett 2012, pp. 236-45)-it is worth emphasizing that, during Nabhadas' period, Sikh numbers were tiny in comparison to those who identified as Vaishnava. To this we may note furthermore that there were, as well, few (if any) Sikhs present near the Galta area of present-day Jaipur in which Nabhadas' Vaishnav Bhakts primarily congregated-a location lauded in traditions surrounding Nabhadas as particularly noted by Priyadas (Hawley 2015, p. 111). The likely early date of Nabhadas' Bhakt-māl, which scholars situate between the years 1585 and 1623 CE (Hare 2011, pp. 44-45), suggests that our famous Bhakt may have simply not come into contact with the Sikhs or those familiar with the hymns of the first Gurus despite the fact that Nabhadas' famous disciple Krishandas Payahari is claimed to have commissioned his Punjabi follower Bhagvan ji to spread Vaishnav doctrines throughout the Punjab Hills (Goswamy and Grewal 1969, p. 7). I would, therefore, and with all due respect, question Professor Hawley's claim in his otherwise excellent book chapter that "the political and anthologizing activities of Nanak's panth make it unlikely that he [Guru Nanak] would have been unknown to Nabhadas" (Hawley 2015, p. 136).

Even if we assume that the latest date of $1623 \mathrm{CE}$ is the most accurate, this would still place Nabhadas' Bhakt-māl around a quarter century before the appearance of the Persian Dabistān-i Mazāhib or The School of Religious Traditions in the early-to-mid 1640s to which we will return. It is quite likely that Mobad Shah, the author of the Dabistān, was familiar with Nabhadas' text perhaps having been made privy to certain features of Nabhadas' rubrics from reading the text itself or from one of his many informants and interlocutors (Hawley 2013, pp. 24-25). It is quite clear, for example, that in regard to the many Vaishnav traditions which our Zoroastrian author describes, Mobad Shah follows the template set by Nabhadas, something that J.S. Hawley had earlier noted especially regarding what was by that time the well-known fourfold classification of Vaishnav teaching traditions, the four sampradāys

3 The difference between Sants and Bhakts, at least since the mid twentieth century, is summed up in the sentence above. Namely, the nature of the deity to which/whom they address their hymns, one with qualities or one beyond qualities. 
or teaching traditions of Ramanuja, Vishnuswami, Nimbarka, and Madhva so eagerly embraced by Maharaja Jai Singh II Kacchvaha in the late seventeenth to early eighteenth centuries (Bahuguna 2013).

Mobad Shah includes the Sikhs within his Hindu category, the latter being one of the twelve such classifications he puts forward, devoting an entire subsection of that category to Guru Nanak and the Nanak-panthis thereby asserting their independent sectarian identity (Behl 2010). This strongly suggests that the mid seventeenth century was a time when Sikhs were more widespread and that this spread reflected larger numbers, a claim that the traditions surrounding Guru Hargobind and Guru Hari Rai, the Sixth and Seventh Sikh Gurus respectively, make clear (Singh 1985; Esfandyar 1983).

Mobad Shah's Persian account of the Nanak-panthis, our Zoroastrian author notes, was produced in part through conversations with both Guru Hargobind and Guru Hari Rai, which makes the Sikh failure to reference his observations in seventeenth-century Sikh literature all the more surprising. The account itself focuses on those elements of the Sikh tradition and teachings that align with the variety of Zoroastrianism that Mobad Shah was attempting to promote, an analysis which draws at least some of its information from the poetry of Bhai Gurdas based on a side-by-side reading of both. In $1689 \mathrm{CE}$, some four decades after the appearance of the Dabistān, moreover, the Mughal emperor Aurangzeb (1618-1707 CE) himself would include in his conversations a śabad of Guru Nanak demonstrating that knowledge about the First Sikh Master and his panth had become more widespread by this point, a pervasiveness seconded, again, by the hukam-nāmās or "written instructions" of the Ninth and Tenth Gurus (Ali 1871, p. 334; Chatterji 1979). It is by this time certainly that Bhai Gurdas' poetic claim in his first $v \bar{a} r$ seems less like exaggeration. To wit,

\section{ghari ghari andari dharamsāl hovai kīrtanu sadā visoā}

Each and every home has become a dharamsala in which the performance of kirtan is an everyday event.

$$
\text { BG 1:27:6 (Singh 1997, p. 22) }
$$

The failure on the part of later seventeenth-century Sikh writers to explicitly engage non-Sikh references to the Sikh Gurus continues throughout the eighteenth century. It is only by the 1800 s that Sikh authors begin to occupy themselves with those who convey interpretations of the teachings of the Gurus in different languages and through uncommon lenses. However, even in these cases, the engagements were between those who understood themselves as Sikh but expressed different ways of being so. Here, I particularly have in mind both Udasi and Nirmala Sikh expressions. Perhaps most famous in this regard is the interpretation of Guru Nanak's Japji penned by the famous Nirmala Sikh Santokh Singh, the 1829 CE Garb Gañjanī Ṭīkā or The Pride-Humbling Commentary (Pradhan 1986). In this case, the pride that Santokh Singh was attempting to chasten was that of the Udasi Sikh scholar Anandghan who was at one time Santokh Singh's teacher and who prepared an interpretation of Guru Nanak's Japji Sahib in 1795 CE that followed an understanding of Sikh tradition and teachings aligned with the Indic-period dharmaśastras. In this, virtually any reference to Hindu deities in Guru Nanak's hymns was interpreted as the First Master's acceptance of the salvific power of said deities (Singh 2000, pp. 249-53).

One could perhaps argue that a part of the reason for the oversight by early Sikh authors noted in the previous paragraphs was the difficulty of language. In regard to early Persian accounts, for example, some Sikhs clearly knew Persian at least at a rudimentary level, in order to deal with representatives of the Mughal administration as the eleventh vār of Bhai Gurdas Bhalla implies (BG 11:2:1; Singh 1997, p. 194). None of these Sikhs, however, appear to have been familiar with the Bhakt-māl prepared by the Afghani poet Ram Soni 'Navanit' in 1682 CE in which Guru Nanak is mentioned (Hawley 2015, pp. 138-39, 225). Nor did they know of the aforementioned Dabistān-i Mazāhib. This was, again, the most sustained early Persian account of Guru Nanak and the Sikhs. Additionally, as stated, the unfamiliarity is striking, especially in the light of the many conversations that Mobad Shah had had with both Guru Hargobind and those within the Sixth Master's entourage (Behl 2010). Finally, let us note that there were also no Sikhs fluent enough to prepare Persian texts on the Gurus and their teachings on their own. 
This situation would change dramatically by the time of the Anandpur Darbar in the later seventeenth century during which Bhai Nand Lal Goya (d. 1713?) wrote what would become his own Persian explorations of Sikh doctrines, which have been allocated the status of bānī or scripture since at least the nineteenth century, his well-known Divān-i Goyā and Zindagī-nāmah (Fenech 2008).

The early encounter with officers of the British East India Company may also be relegated to this unfamiliarity with language, moreover, English in this case of course, a situation that was only remedied in the 1960s and 1970s with the appearance of Ganda Singh's Early European Accounts of the Sikhs which brought together a number of articles he had earlier penned (Singh 1974). Here, Ganda Singh's approach became the standard with which all such seventeenth- and eighteenth-century non-Sikh views would be confronted in future scholarship, adopting as a measuring stick the modern interpretation of Sikh history and doctrine forged in the early twentieth century by the Singh Sabha/Tat Khalsa. In this reading, those elements in early European accounts that steer away from more recent emic interpretations are deemed incorrect, a discussion which occurs throughout Ganda Singh's lengthy footnotes in his Early European Accounts. This forms a way of reading these early texts that our esteemed author also brought to bear in his English translation of the respective portions of the Dabistān-i Maz̄ăhib in 1940 (Singh 1940). This style of exegesis of course was established well before Ganda Singh and may be clearly witnessed, for example, in the writings of the famous Max Arthur Macauliffe, especially his six-volume The Sikh Religion. Macauliffe's own interpretations of the Sikhs and Sikh history and religion as he tells us in his Introduction was scrutinized and ultimately amended by those very ideologues of the Singh Sabha/Tat Khalsa whose bias Ganda Singh clearly shared (Oberoi 1994).

\section{Raghavdas, the Dadu-Panth, and the Bhakt-māl}

If language may be put forward as an excuse for the disregard of early non-Sikh accounts of Guru Nanak and interpretations of his doctrines, then such an explanation can in no way account for the neglect of those non-Sikh works in the same general language as those written by Sikhs about their Gurus, that is works in Brajbhasha. By the eighteenth century, Sikh authors wrote almost exclusively in Brajbhasha, a language spoken throughout the Indo-Gangetic plains. It is in Brajbhasha that the vast majority of Guru Gobind Singh's works are conveyed, those of the poets within his literary darbar, and, too, it is in Brajbhasha that the eighteenth- and nineteenth-century gur-bilass, literature highlighting the mighty battles of Guru Hargobind and the Tenth Guru, was prepared. Reasons for this linguistic choice are many, one of which has to do with the fact that this language was embraced by both the Mughal court and those literary courts surrounding the Tenth Guru in Pahari Punjab while he resided in Anandpur (Fenech 2008). While Nabhadas' pioneering Bhakt-māl in Brajbhasha may make no mention of Guru Nanak and the Sikhs for the conjectured reasons noted in the first section of this paper the next most famous entry within the Bhakt-māl tradition, one whose author self-consciously fashioned his text with that of Nabhadas in mind (as he often relays), remedies that situation quite adequately. I am speaking of the Bhakt-māl of the Dadu-panthi Raghavdas.

Both the Dadu-panthis and the Sikhs share a number of features though few within the Sikh sphere would mention the saint Dadu (1554-1603 CE) in the same breath as the Gurus of the Sikh tradition, perhaps because none of the many compositions attributed to Dadu were included in the Guru Granth Sahib's Bhagat Bani (Singh 2003). Such notwithstanding, though, one would be hard pressed to ignore the keen similarities between Sikh sangats and those communities dedicated to Dadu in the light of Raghavdas' description of the Dadu-panth which appears in his Bhakt-māl. Let me reproduce one example here:

dādū kerā panth mai chain chatur chit charan hari

kathā kīrtan prìti het saum hari jas gāyā

sathi ra rahai samāj prem parbraham lagāyā 
Contentment and intelligence both preside within the Dadu-panth alongside a focus on the blessed feet of Hari.

[Uplifting] homilies (kathā), congregational singing (kīrtan) and love, all here reign; all here are performed for the sake of singing the grandeur of God.

The society [of Dadu] remains bound together, all of which engenders love for the transcendent divine (parbraham).

Bhakt-māl 509:1-3 (Nahta 1965, p. 235)

Indeed, by the late eighteenth century Dadu-panthi and Khalsa Sikhs both possessed extensive and systematically arranged anthologies of poetry, both expressed martial dimensions within their respective traditions while simultaneously embracing both a general Sant emphasis on the transcendent and unqualified divine; both enjoyed, as well, an interior discipline by which one could attune oneself to that divine which reverberates throughout the universe, as demonstrated above (Pinch 2006). At a much more mundane level, too, both communities were generally prospering economically by the late eighteenth century, benefitting from the many changes precipitated by the various transformations of the Mughal empire after the sack of Delhi by Nadir Shah in 1739, and were composed of those who embraced more ascetic lifestyles (Sikh Udasis and Dadu-panthi sadhus and sadhvis) as well as those who did not, particularly lay followers and householders (Dhavan 2011). As Raghavdas intones, $d \bar{a} d \bar{u} j \bar{\imath}$ ke panth maim mahant sant surbir , "within the Panth of the revered Dadu are found mahants (deputies), Sants, and brave warriors" (Nahta 1965, p. 187). Assuming that stories of Khalsa Sikh-Dadu-panthi interactions were apocryphal one may surmise that it was such alignments that prompted the very few interactions between Khalsa Sikhs and Dadu-panthis recorded within Sikh tradition. We witness episodes in Sikh literature, for example, in which Guru Gobind Singh passes by the shrine of Dadu and tips his arrow towards it as a sign of respect. To this, we may add a fascinating anecdote in which the Tenth Guru converses with the famous contemporary early eighteenth-century mahant of the Dadu-panth, Jaitram. Although it may be as well that in his travels southward Guru Gobind Singh could certainly have stopped at Dadu's dharmsala at Naraina as he made his way southwards to Nanded in the first decade of the eighteenth century, a point noted by J.S. Hawley, and mentioned by Macauliffe (Hawley 2015; Macauliffe 1990).

Despite such interactions imagined or otherwise, we hear no references at all in Sikh sources to who is perhaps the most famous of Dadu's disciples, Raghavdas, a fame that was launched in large part because of his Bhakt-māl (Callewaert 1994). This ignorance is surprising given the facts that Raghavdas' text is apart from the Dabistān the earliest of the non-Sikh texts that speak lovingly of the First Master, his family, and his successors, and that Raghavdas was familiar with the janam-sakhis (one story of which he summarises in his Bhakt-māl) and (as I will later argue) with the writings of Bhai Gurdas. It may have been Raghavdas' disposition towards Guru Nanak and his Panth that prompted the authors of the nineteenth-century Gurū kīann Säkhīann and the earlier Parchīān Sewwādās in which we find these Dadu-panthi references to introduce such characters from the domain of the Dadu-panthis to interact with the Gurus of Sikh history and Sikh memory (Padam 2003, p. 192; Singh and Singh 1995, pp. 157-58). Since the time of this early Brajbhasha bhakti work, Guru Nanak has been effortlessly situated within a bhakti environment, a fact that continues today as the abundant number of images of the First Sikh Master for sale along the many streets around the Durgiana Temple in Amritsar testify (Chopra 2018, p. 59).

Although Raghavdas' Bhakt-māl is the earliest non-Sikh Brajbhasha reference to the Sikh Gurus, exactly how early this text appeared is a matter of ongoing debate. Of all the present issues surrounding Raghavdas' fascinating text, the most tenacious is its dating, whether it was written in late June of samvat 1717, 1770, or 1777 which correspond to 1660,1713 , and $1720 \mathrm{CE}$, respectively. These dates result from the confusion engendered by the word satrahaumtara in the line that begins sākhī 19:555, which has been interpreted as 17,70 , or 77 . The line is reproduced immediately below: 
sambat satrah sai satrahauṃtarā sukal pakṣ sanivār

tithi tritīyā āṣād kì rāgho kìyau vichār

[This text was completed in the year] sambat 1717 [or 1770 or 1777], on Saturday the third lunar day of the bright half of the month of Āsād [h]. [It was at this time that] Ragho's thought was made manifest.

Bhakt-māl 19:555 (Nahta 1965, p. 246)

Such dating controversies would not be worth mentioning in this paper except for the fact that the text's date does not easily accommodate a claim made within Raghavdas' description of the Sikhs. In his depiction of the Nanak-panth, what Raghavdas titles Śrī Nanak ji kau panth varnan, we have a very problematic clue as to this dating. The passage in question mentions all of the Sikh Gurus in their capacity as Guru in chhappai 348 (A chhappai is a six-verse stanza with the first verse generally appearing at the end as well) except for Guru Tegh Bahadar and Guru Gobind Singh. At first glance, the date thus seems straightforward, indicating that the earliest date of 1660 is the most likely since Guru Tegh Bahadar became Guru in August 1664 CE. The issue is complicated, however, because Raghavdas also mentions Hari Krishan as Guru. As far as I am aware, this discrepancy was first pointed out by Winand Callewaert some years ago, namely that the young Hari Krishan did not become Guru until 1661, a year after the alleged early date of Raghavdas' Bhakt-māl (Callewaert 1994, p. 96; Singh 1977, p. 113). Now, all of this suggests that the Raghavdas text appears after 1660 and, therefore, scholars like Callewaert claim the more accurate dates are the later ones. Callewaert, for example, sets his sights on S. 1777/1720 CE (Callewaert 1987, p. 186).

Although most scholars today (but not all) simply mention the controversial nature of the dates and forgo involvement in the text-dating controversy, in large part because of this Sikh-related evidence (most nevertheless imply that they are sympathetic to the later dates), the editor of the 1965 edition of the Bhakt-māl on which most scholars rely, Agarchand Nahta and, too, the Dadu-panthi scholar Monica Horstmann, both support the S. 1717/1660 CE claim. Horstmann in particular bases this on certain chronological and astronomical evidence among other points: for example, S. 1717/1660 CE was the only year in which the specific Saturday mentioned aligns perfectly with the description at $s \bar{a} k h \bar{\imath}$ 19:555 (Horstmann 2000, p. 515, n. 9). While both Nahta and Horstmann seem to simply ignore the problem engendered by the Guru Hari Krishan reference, those who accept the later eighteenth-century dates make no attempt to explain the absence of the Ninth and Tenth Gurus. One could perhaps argue that Raghavdas uses the term sāhib-zāda to refer to 'householder' Lakshmi Das one of Guru Nanak's sons in chhappai 347:2 (Nahta 1965, p. 176), a term that did appear in Sikh literature by the early eighteenth century to describe the sons of Guru Gobind Singh, and that this could, therefore, be a veiled reference to this later period and the chār sāhib-zāde of Sikh tradition (the same may be said for Raghavdas' reference to ammrit at 342:5 ( $a m \bar{\imath}$ in the text)). Or one could also conjecture that Raghavdas, with his penchant for categorizing groups into sets of four (an inclination to which he readily succumbs in his passages on Guru Nanak as we will see), would have neatened up the lineage of Sikh Gurus in his reckoning by reducing them to a tidy eight rather than focus on a less neat 10 (although there are instances when Raghavdas does point out a group of five) (Nahta 1965, p. 239).

However, both of these claims (and, too, that of the ammrit/amì) are rather flimsy to me and the former still fails to explain the absence of the two last human Sikh Gurus. Could Raghavdas have understood the Khalsa-which he may have extended backward to the time of Guru Gobind Singh's father Guru Tegh Bahadar-as a group that was distinct from those Sikhs committed to Nanak, the Nanak-panth and thus have purposefully ignored the Ninth and Tenth Gurus? Mughal documents, for example, certainly note a difference between those whom they refer to as the Nānak-parastān and the Khalsa Sikhs of Gobind Singh, perhaps indicating the differences between urban Khatri Sikhs who were generally integrated into the Mughal economy and administration and did not embrace the Rahit of the Khalsa and rural Jats who formed the bulk of the Khalsa (Alam 1986, pp. 169-75). 
Whatever the case may be, what seems to make sense to me as a way of suggesting a path beyond this impasse is to propose that the date at $s \bar{a} k h \bar{\imath}$ 19:555 indicating the absolute completion of the text is simply incorrect as surely as it must be-perhaps appropriated to fit the meter of the poetry by Raghavdas or simply convoluted by later copyists; after all, the earliest extant manuscript of this Bhakt-māl is $1804 \mathrm{CE}$. The circumstantial evidence strongly suggests that the text was prepared sometime after the Eighth Guru ascended the gur-gaddi in 1661 but before the death of Guru Hari Krishan in 1664. This would most certainly explain why Raghavdas fails to mention both the last Sikh Gurus as well as the Dadu-panthi reformer Jaitram to whom we were earlier introduced as Guru Gobind Singh's conversation partner, who flourished between 1693 and 1732 CE an absence which, Horstmann notes, "would have been simply unthinkable" if the text was composed during the later dates proposed by various scholars (Horstmann 2000, pp. 515-16). Although this cannot yet be proven without a doubt, the incidental evidence at our disposal adds more weight to the earlier period than to the others without specifying the exact date that 19:555 lays bare. Put simply, this Bhakt-māl appears to most likely be a mid-to-late seventeenth-century product.

With that out of the way for now, let us focus specifically on the portion of Raghavdas' text that deals with Guru Nanak for the rest of this paper.

\section{Introducing Nanak: Gurū, Bhakt, Mahant}

Certainly the Lion's Share of the portion of Raghavdas' Bhakt-māl in which Guru Nanak is situated focuses upon Dadu Dayal and his disciples, significantly numbering 52 (which is, I should note, divisible by four), amongst whom are included Garibdas, Sundardas, Rajjab and a host of others (Horstmann 2015, p. 38). This is of course completely understandable given the fact that Raghavdas' own guru is Dadu and glorifying his teacher and the latter's panth are among the stated goals of the text. Although the first portion of Guru Nanak's description does not name the First Master or any of his fellow Sants/Bhakts specifically (the following chhappai will make Guru Nanak's identity in the preceding chhappai abundantly clear), Raghavdas, we will soon discover, nevertheless implies Guru Nanak in his statements and includes him within this relevant segment, in two sets of four evenly apportioned chhappais in the Bhakt-māl, both sets of which have additional internal symmetries. These two sets comprise the only references to Nänak (implicit and explicit) throughout the text of the Bhakt-māl, the only figure in this particular collection of eight chhappais who is able to don many hats—or, better yet, tie multiple turbans upon his head-in this case, that of mahant, Bhakt, and Guru, all of which appear equated in the description of Baba Nanak.

This first quartet of chhappais begins by aligning two foursomes, an earlier sagunī group and a later $n r g u n \bar{\imath}$ set of four mahants (341)—as Raghavdas calls them—in a pattern that is somewhat recreated at the end of this first arrangement of four chhappais (344). The middle two chhappais, then, first describe the nrgun teachers who are Nanak's fellow Bhakts and very briefly note their understandings of God (342), after which attention is turned towards the sagun claims of the former preceptors (343) which sound in many ways like those of their later $n$ rgun incarnations.

It is in the first (chhappais 341-44) that our Dadu-panthi author accommodates Guru Nanak, lodging him within the easily recognizable Vaishnava framework mentioned above, that of the four sampradāys or four teaching traditions which we earlier encountered in the Bhakt-māl of Nabhadas who is among the earliest writers to appropriate this scheme as his point of departure (Hawley 2015, pp. 119, 127). This should not provoke amazement since Raghavdas, like others before him, "depicts [the fourfold scheme] as providing the key to religious order in the Kaliyuga", as Hawley has noted (Hawley 2013, p. 30). Additionally, this is despite the fact that our Dadu-panthi author-for whom the fourfold scheme is quite central let us reiterate-nevertheless appears to occasionally push against this classification (Hawley's golf metaphor that "a certain amount of rough persists" is especially appropriate here) (Ibid), perhaps most transparently when the fourth of this tetrad is identified as Jagan (also jagat) (Nahta 1965, p. 21). Jagan is used to denote not only one other nrgunī Bhakt, but we may infer all others who speak of the divine as Niranjan, the Hari-Niranjanī, the descriptions of which 
end at chhappai 444 in the Nahta edition (Nahta 1965, p. 206; Williams 2014, pp. 143-56). It is within this four-square rubric that Guru Nanak is connected to (and, from my Sikh-centered perspective, limited by) Dadu, Kabir, and Jagan, as we shall see, as well as to the previous progenitors of the earlier sampradāys of southern India and beyond (Nahta 1965, p. 48 ff.). Much has been written about these original four traditions, at this point focusing on both the sampradây-ness of the construct and its foursomeness (Hawley 2015, pp. 99-147), the latter of which Hawley insightfully notes adds an immovability to a situation which is far less stable in reality. The "panthicness" of their later incarnations, however, has yet to be explored thoroughly (Khan 2004, p. 22; McLeod 1978).

In the second set of four chhappais, which comprises chhappais 345-8, we are treated to a discussion of Guru Nanak himself who was, we are told, born into a family of Kshatriyas (345), yet spent his time in fields grazing his buffaloes (a non-Kshatriya past time) where eventually he meets with the Eternal Brahman. After this a few words are spared to discuss the First Master's nrgunī understanding of the divine (346) and this brief account is then concluded by making us privy to the First Master's double lineages, biological and spiritual: one being his immediate family, particularly his sons (347), and the other, the next seven successors to the guruship (348). The joti or divine light of Guru Nanak, Sikhs note, was passed on to all of these individual successors on their accession to the gur-gaddi thus transforming them into Guru Nanaks, if you will, an understanding instantiated into both the poetry of the Guru Granth Sahib itself and its very structure and likely implied in Raghavdas' chhappai 348 (Guru Granth, p. 966; Hawley 2013, p. 31) ${ }^{4}$ (perhaps the line which appears as our epigraph suggests as much). In the biological lineage, moreover, we are also introduced to the spiritual descendants of Guru Nanak's celibate Udasi son, Siri Chand, who is counterpoised by Guru Nanak's householder son Lakshmi Das although both, Raghavdas intones, are ubhai brāt bhakt hari ye "great Bhakts of Hari" [347:1], drawing attention to a binary which Hawley discusses in the context of both Mobad Shah and Nabhadas as well as Raghavdas (Hawley 2013, pp. 24-25), all of whom also total four and all of whom occupied the four principle directions thus adding a further symmetrical dimension to the entire two sets of four chhappais: Guru Nanak as part of four in the first quartet and Guru Nanak giving rise to a further four through his offspring in the second, the Master whose substance spreads throughout the four cardinal directions through these latter four, thus suggesting the universal coverage Hawley notes and which we see relatively frequently in the first $v \bar{a} r$ of Bhai Gurdas. Much of this vār carries the spirit of the janam-sakhis, a point to which we will turn momentarily (Hawley 2013, p. 30). Let us now, though, take each one of Raghavdas' sections (341-4 and 345-8) in turn.

\section{Nanak and the Chaturpanth}

In the first, Raghavdas introduces us to the chaturpanth, the Four Panths of the four traditions. This construction was something novel in the Vaishnava understandings of Raghavdas' day, shifting to one side but not displacing what were previously described by Raghavdas and earlier Nabhadas as sampradāys or teaching traditions (Nahta 1965, p. 48). Here, in the first chhappai, it is upon the shared teachings of the collective four that he focuses rather than on the chaturpanth's individual components. Raghavdas will see Guru Nanak (without naming him at this point) as the foremost of the chaturpanth's four equal constituents a point we will attempt to explain momentarily. As Hawley has noted the appropriation of the term panth rather than sampradāy is here significant (Hawley 2013, p. 30) and appears to draw upon a taxonomy commonly used among the Sikhs who were more well known in this period as Nanak-panthis.

Put simply, Raghavdas was aware of the fact that Guru Nanak's teachings were never referred to as a sampradāy in early Sikh literature even though technically they do form one. This choice of panth rather than sampradāy demonstrates Raghavdas' cognizance that these were not limited teaching traditions, but more inclusive communities, publics which include all people, religious practitioners

4 All references to the Adi Granth/Guru Granth are drawn from the standard printed edition of 1430 pages. 
and specialists, and lay people alike, a construction with which Raghavdas would have been mightily familiar given his place in the Dadu-panth which was likewise composed of all types of people, including women (of course), as well as many converts from Islam (Nahta 1965, p. 201; Bangha 2015). The understanding Raghavdas appears to communicate through his appropriation of the term panth suggests a transition from the orthodox to the vernacular, from the scriptural to the level of everyday lived religious life-the quotidian. The use of this descriptive, moreover, could be perhaps the reason why Guru Nanak is placed in the primary position in this construct as we shall note in a moment, a testament to the growth of the Sikh or Nanak-panthi community in the later seventeenth century. Although it should be added that Raghavdas' use of the term panth, a word so commonly used to describe groups of disciples which surrounded Nanak, Kabir, and Dadu in the late seventeenth century would have allowed Raghavdas' audience to take for granted the identities of the four.

Simultaneously Raghavdas uses descriptives in his introductory line that further connect his text to the Bhakt-māl of Nabhadas-something he regularly does (Hawley 2013, p. 45, n. 27). In the process of so doing he stretches the lineage of the four new mahants to those of their legendary predecessors, that is the earlier-mentioned Ramanuja, Vishnuswami, Nimbarka, and Madhva, respectively-teachers now turned mahants by Raghavdas. Such a stretch connects both sets of panths, structurally and temporally, as Hawley has speculated, bringing order to what was surely an incredibly diverse and vibrant socio-religious environment-despite the stereotypes that surround the rule of the Mughal emperor Aurangzeb (1618-1707 CE)—engendered in part by the generous policies of the emperor Akbar (1542-1605) almost a century earlier. These were policies that helped give rise to the type of "Vaishnava catholicism" to which, Vijay Pinch mentions, Nabhadas and later Raghavdas gave voice (Pinch 1999, pp. 369, 394 ff). This in turn ultimately traces the lineages of Guru Nanak and his three co-mahants back even further to the pre-eternal, beyond the apparently southern progenitors of bhakti to the latter's very "primordial anchors" (Hawley 2013, p. 21) which include Shiva (Shankar), Lakshmi, the Kumara Sanaka (one of the four Kumaras) and the latter's father Brahma (noted at chhappai 343:2-5). In the first line of chhappai 341 , this connection and all that it implies is immediately noted:

\section{vai chyāri mahant jyūṃ chatur vyūh tyum chatur mahant nrgunī pragat}

Truly, in the same way that the four [earlier] mahants appeared as four flanks of the divine army [in ages past] so too did the $n r g u n \bar{\imath}$ mahants [of the present age] become apparent.

\section{Bhakt-māl 341:1 (Nahta 1965, p. 175)}

This correlation between the two sets of mahants is further elaborated in chhappais 342-43: in the first, Raghavdas describes the four nrguni mahants while in the latter we are treated to a description of the four sagunī/trigunī masters. As we read through these poetic descriptions, a cumulative effect emerges in which an equivalency is drawn between the two sets of mahants. This parallel is sustained throughout the first quartet of chhappais ending at 344. Here, in 344, the mahant lineage is extended to the pre-eternal. Just prior to this, though, we see that this correspondence is manifestly proclaimed in the single line which bookends chhappai 343 regarding the saguni mahants:

\section{in chyāri mahant trigunīn kī padhit sūṃ nirañjan milī}

These four were mahants of the qualified Divine of the three constituent qualities of all matter. Through their path one is led to the Purest One, the Lord who is Niranjan.

\section{Bhakt-māl 343:1 (Nahta 1965, p. 175)}

In describing the sagunī/triguni goal as the Niranjan, the Most Pure [divine], Raghavdas connects this ultimate end to the shared characteristics and terminal goal of the nrgun $\bar{\imath}$ mahants implied in chhappai 341 and described in 342. Simultaneously, any kind of distinction between those who preach of the nrgun deity and those of the sagun divine is blurred. The division between these two sets, therefore, may not be as explicit as, for example, J.S. Hawley suggests, though even his proposition is tempered as he continues his insightful discussion (Hawley 2013, p. 30). As many scholars have noted, 
this difference is more likely a distinction that is situated within academic discourse rather than in the understandings of the Sants and Bhagats themselves, although a more sustained study of Raghavdas' Bhakt-māl will likely allow that claim further nuance (Hawley 2005). Outwardly different, it appears that the two sets of four are, nevertheless, connected for Raghavdas, as both sets of teachings lead towards the ineffable Lord, the object of both sagunī and nrguni mahants. Indeed, my translation of 341:2 — which differs from Hawley's (Hawley 2015, p. 130)—underscores this point a little more clearly.

sagun rūp gun nām dhyān un bibidhi batāyau

The form of the sagun is the quality (gun) of the nām, which people have contemplated and described in all sorts of myriad forms.

Bhakt-māl 341:2 (Nahta 1965, p. 175)

It is this $n \bar{a} m$ which forms a significant facet of the divine self-expression in the $b \bar{a} n \bar{\imath}$ of the Sikh Gurus, through which Baba Nanak will become "dyed in the love of Hari" (346:1). The totality within the singular is certainly a theme we regularly discover in Guru Arjan's description of the divine as both sagun and nrgun:

nirguṇu āpi sargunu bhī ohī/kalā dhāri jinni sagalī moh̄̄

The divine is beyond qualities (nirgunu) while simultaneously with qualities (sargunu). Infusing the entire world with energy, the divine enraptures all.

(Guru Granth, p. 287)

Within the same chhappai 341, Raghavdas then goes on to explain the shared characteristics of these nrgun teaching traditions by focusing upon the transcendent and unknowable nature of the divine each privileges, a divine which is characterized by the nām as above which is both agun or outside of the three constituent qualities of all matter as well as arūp, beyond all form. He continues:

nirlep nirañjan bhajan kaum sampradāi thāpī sughat

These teaching traditions were well established and firmly constructed to praise That One who is unsoiled, That One who is immaculate (nirañjan).

Bhakt-māl 341:5 (Nahta 1965, p. 175)

This is That One, "the knowledge of whom", we were previously told, allows all people "to conquer the world" (aql jag sakal jitāyau) [341:3], which continues the martial metaphors used throughout Raghavdas' descriptions, perhaps suggestive of the type of armed ascetic militancy both Dadu-panthis and Khalsa Sikhs of the Gurus shared in the later seventeenth century.

The nature of the divine discussed here appears to mirror the type of transcendent language we discover within the Sikh mūl mantar that begins the Adi Granth. It is only fitting, then (given the similar goal to which all eight masters point), that within the final of the first set of four chhappais (344), Raghavdas further establishes the connection between the four southern mahants and their northern successors, between the nrgun and the sagun, that we recognize at the very beginning of 341 more firmly by bookending the last canto of our first quartet, chhappai 344, with the same line glorifying both Guru Nanak and Dadu in much the same way that the bookending line of chhappai 341 first connects the two sets of four mahants by allusions to Nabhadas' own description of the southern four mahants:

\section{jan nānak dādūdayāl rāgho ravi sasi jyūụ dipai}

Both the beloved Nanak and Dadu Dayal, O Ragho, shine together as the sun and moon.

(Bhakt-māl 344:1 Nahta 1965, p. 175)

Between this repeated line are five others for a total of seven: two connecting the saguni four to their godly anchors (344:2-3); two describing these same four as being the divinized human embodiments of well-known miraculous items such as the Philosopher's Stone and the Wish-fulfilling Cow (4-5) among others, and a fifth which ties the two sets of traditions-four sampradāys and four mats-together: 
ye chyāri sampradā chyāri mat kṣat ūpari katahum na chhipai

As a raised, trusty umbrella ( $k s a t$ ) under which nothing can hide these four teaching traditions and these four doctrines offer protection that is all encompassing.

$$
\text { Bhakt-māl 344:6 (Nahta 1965, p. 175) }
$$

However, while the nature of the divine is discussed in the first chhappai, as too are established connections between southern and northern exponents of bhakti, the identities of those who advocate these understandings of the divine have yet to be divulged. It is in the opening line of the following chhappai that we are finally introduced to the names of the nrguni mahants, in which, as noted, Nanak appears as primus inter pares:

nānak kabìr dādu jagan rāgho paramātmā jape

Nanak, Kabir, Dadu, and Jagan, o Ragho, all praise (jape) the Supreme Being!

$$
\text { Bhakt-māl 342:1 (Nahta 1965, p. 175) }
$$

This is the chaturpanth the final three of which are metaphorically likened throughout the respective chhappai to facets of nature that refer to liquid, all of which focus on nurturing and nourishment. We began this paper with the epigraph likening the light of the kingly Guru Nanak to that of the sun. The next three lines in which his fellow mahants are praised similarly follow:

madhvā dās kabīr ūsar sūsar barakā se

dādū chand sarūp amī kari sab kauṃ poṣe

karan nirañjan̄ manaum trișā hari jīo santoṣe

Like Indra, Dās Kabir, drenched the cracked and parched world in rain while Dadu's true form is that of the moon, nourishing everyone with the nectar of immortality $(a m \bar{\imath})$. And [Jagan] the follower of the Purest One, who is like Varuna quenching the thirst of all with the elixir that is Hari.

Bhakt-māl 342:3-5 (Nahta 1965, p. 175)

These are easily among the most common literary conceits by the mid seventeenth century, alignments which Raghavdas also established with the many other Bhakts that populate his text. What is intriguing in this regard, too, is the potential association with the legendary lineages from which the Rajput patrons of the Vaishnav sampradāys proclaimed themselves to be descended. In their traditional pedigrees, various Rajput clans boast of their descent from either the chandrabaimsi and the suryavaimsi, the sun and the moon lineages which trace their origins to Ramchandra or the Pandavas. It is no surprise that a few decades later Guru Gobind Singh will likewise establish such connections between these lineages and those of the Sikh Gurus in the fifth chapter of his Bachitar Nätak.

\section{6. Śrī Nanak Ji Kau Panth Varnan: Bhai Gurdas Bhalla and Raghavdas}

There are still facets of the first quartet of chhappais that require examination (the specific ordering of Bhakts we note at 344:1, for example), but it is time to turn attention to the next set of four in order to situate these considerations in the context of the first and explain them more thoroughly. By doing so, we can more systematically answer these lingering questions.

In the article which engendered my interest in Raghavdas, that insightfully examines the foursomeness of the four-sampradāy construct, Professor Hawley indirectly asks a pertinent question about Dadu's position in this later nrguni quartet: why would a devout Dadu-panthi like Raghavdas place his own beloved guru in the third position here rather than in the first? (Hawley 2013, p. 31). Since the grandeur of Dadu is described throughout Raghavdas' Bhakt-māl as we note, for example, a few chhappais within the chaturpanth segment after the discussion of Nanak and the Nanak-panth, I think that the key to answering this question lies not in an examination of Raghavdas' attitude towards 
Dadu or Dadu's immediate precursor in the Bhakt-māl portion under discussion, Kabir, but rather to Guru Nanak specifically, and this, too, is something that Hawley implies in his attempts to answer his own question.

Of course, as a scholar of Sikh tradition I would pose the query a little differently: why does Raghavdas place Guru Nanak first? I think, as does Hawley, that the context in which Raghavdas is writing supplies the key to this answer. However, while Professor Hawley rightfully reasons, among other things in his article, that perhaps the prestige of the Adi Granth (in the late seventeenth and early eighteenth centuries) or the fact that Nanak preceded Dadu chronologically awarded the revered First Guru the primary position, I would like to veer the discussion into other, though clearly related, matters and texts.

Raghavdas is certainly aware of the recognition of Guru Nanak in the late seventeenth century. The line which both begins and ends the first chhappai (345) in this new set of four is a testament to the popularity of the First Sikh Master, the mahant who is both Guru and Bhakt:

uttar dis utm bhayo nrgun bhakt nānak gurū

The northern country became exalted because of the nrgun Bhakt, Nanak Guru.

$$
\text { Bhakt-māl 345:1, } 7 \text { (Nahta 1965, p. 176) }
$$

Raghavdas includes the uttar dis or northern country here because, let us recall, for many writers like Raghavdas and those who were identified as Bhakts or Bhagats, the format of the four sampradāys moved from southern to northern India, giving the construct a certain gravitas in seventeenth-century northern India, despite the fact that the apparent geographical movement from south to north was likely a product of northerners themselves, failing to altogether animate the imaginations of their south Indian predecessors or contemporaries (Hawley 2015, pp. 59-98, 99-100, 116). It also appears to add another dimension to Raghavdas understanding of the Sikh tradition, in this case regarding the First Guru's son, Siri Chand, whom we will encounter momentarily. Here, though, is the first line which speaks of Nanak in his capacity as teacher or gurū an illustrious description which should rightfully be reserved for the portion of the Bhakt-māl, which more systematically singles out Guru Nanak and which is repeated within three of the four chhappais of quartet two-chhappai 346 forming the sole exception. (Interestingly, Raghavdas only refers to Nanak as Guru in lines in which he appears without his Bhakt companions.) Immediately before the final line of 345, moreover, we have another reference to north India situated within an allusion to what is today a well-known śabad of Guru Nanak, ślok vārān te vadhīk 20 (Guru Granth, p. 1420). Here is Raghavdas' chhappai 345:6:

sīs hāth dhari yaum kahayau nroun bhakti vistār kurū

Having placed his head on [the palm of] his hand he preached and spread the doctrine of nrgun bhakti [throughout the land of the] Kuru.

Bhakt-māl 345:6 (Nahta 1965, p. 176)

The [Land of the] Kuru refers to the northern India which forms the northern area between the Ganga and Jumna Rivers in which the events of the great Sanskrit epic, the Mahabharata, take place. This allusion to Nanak's hymn of total commitment while travelling along the path which leads to the divine and, too, the exalted designation as guru in the line immediately afterwards bring to mind the writings of one of Raghavdas' close predecessors to whom we have already been introduced, the famous Bhai Gurdas Bhalla, whose magnificent poetry forms the related texts I noted above, which are germane to my discussion.

Bhai Gurdas, easily one of the most important early writers of the Sikh tradition, makes proclamations quite similar to those we see above in Raghavdas and ones even more lofty in his first $v \bar{a} r$, an ode which bears much resemblance to the early janam-sakhis and which was likely added to the collection of vārann much later than the bulk of the collection's contents (McLeod 1980a, pp. 43-45). Note, for example, a line from the 23rd pauṛi of said first vār which resonates at a pitch remarkably similar to Raghavdas' chhappai 345:1 above: 
pārbraham püran brahamu kaliyugi andari iku dikhāiā

[Guru Nanak] preached during this ultimate age of degeneracy in the cosmic cycle, demonstrating that the Eternal Brahman beyond conceptualisations (pārbraham) is [the same as that] perfect Brahman confined by the intellect.

(BG 1:23:3; Singh 1997, p. 318)

Certainly, as Gurdas likely intended, one could effortlessly substitute nirgun (nrgun) for pārbraham and sagun for brahamu in this line and conclude that the sentiment Gurdas' vār evokes is that same one we discover within Raghavdas' Bhakt-māl. Should it, therefore, occasion any wonder that Gurdas' vārs would eventually form the structure on which eighteenth-century Sikh writers would hang the uniquely Sikh Bhakt-māl, the Sikkhān dī Bhagat-mālāe (Bedi 1994) The creation of this text in and of itself suggests an engagement with Raghavdas, further underscoring the independent sectarian nature of the Sikhs that Raghavdas was attempting to compromise.

I single Bhai Gurdas out at this point, therefore, for good reason. We mentioned our Bhalla author earlier in regard to Nabhadas; I would like to continue to draw on this connection for the next few paragraphs with the opening suggestion that it was perhaps Nabhadas' Bhakt-māl or the traditions which gave rise to Nabha's Garland of Saints that prompted Gurdas to craft and arrange certain vārs in his collection in a very specific way. This would include, as I have implied above, the first $v \bar{a} r$.

As we have seen recent scholarship on the vārs of Bhai Gurdas has argued quite persuasively that Gurdas' collection was originally composed of 34 vārs which would, sometime later, in the early 1620s, be bookended by two sets of three odes on either side for a total of 40 (Gill 2017). A number of reasons have been put forward as to why Gurdas chose to revisit and augment his collection of vārs. One such posits that in doing so Gurdas was attempting to contest the implicit claims to legitimacy put forward with the production of the Miharban Janam-sakhi (finalized 1618-19), Miharban being an exponent of a variety of Sikh tradition considered heterodox by Gurdas (Gill 2017). This is a credible argument. Given the fact that Nabhadas' text was composed much before or just prior to the time when these later vārs were added, however, it is very tempting to suggest another: that Gurdas' first $v \bar{a} r$ and its almost janam-sakhi-like focus on Guru Nanak may have been prepared in order to rectify that which was ignored by Nabhadas, to elevate Guru Nanak to the level (and indeed beyond that) of the Bhakts Nabhadas so lauded in his collection. Gurdas does this in such a way as to ensure that the distinct sectarian identity of Guru Nanak and his Sikhs or Nanak-panthis is not blurred in the way that Nabhadas mashes together all those saints strung along his garland. Indeed, unlike Nabhadas, who may have simply ignored those Pirs, Bhakts, and others from whom his position differed, Gurdas is apparently not shy in identifying those with whose positions he disagrees, most infamously the minnas, those "scoundrels" who claimed the Sikh guruship for themselves without having had it legitimately bestowed upon them (Grewal 2007, pp. 35-36; Singh 2006, pp. 35-36).

Thus, although Bhai Gurdas' poetic explication of Sikh doctrine shares many affinities with those bhakti traditions championed by Nabhadas and later Raghavdas and their commentators, Gurdas' is a tradition, we see from his poetry, that nevertheless significantly differs. For example, Bhai Gurdas underscores this variance by pointing to the inverted Sikh ritual of incorporation into the Nanak-panth, charanamrit or "foot-nectar", whereby members of the gathered sangat would drink the footwash of the newly initiated, a clear demonstration of the type of humility to which both the Sikh Gurus and Bhai Gurdas enjoined all Nanak-panthis to aspire (Gill 2017, pp. 56-66). This inducting ritual stands in marked contrast to the far more common ceremony in which the Guru's toe-wash would be imbibed by that person seeking initiation. There is, too, the fact that Gurdas chose to convey his thoughts predominantly in the vār format rather than in the chhappais so loved by Nabhadas and other authors of the Bhakt-māl genre, vārs being, apparently, the preferred genre for Punjabi poetry which attempted to evoke the "heroic sentiment" or bir ras (Gill 2017, pp. 41-55). Finally, Gurdas, unlike Nabhadas and Raghavdas, subsequently is not willing to allow any other Sant/Bhakt/Bhagat to occupy the same stage as Guru Nanak or any of the other Sikh Gurus. 
Gurdas may have personally cultivated such heroism and humility through his journeys. We must recall that Bhai Gurdas was, it appears, very well travelled and a likely consequence of that travel was a cognizance of the sangats scattered throughout northern India, something to which the vārs readily testify. This would certainly have augmented Gurdas' keen familiarity with Indic and Islamicate traditions as well as the relatively new bhakti traditions enshrined within much of the Brajbhasha literature which emerged in his period, which, once again, was a time marked by a generousness of religio-cultural ideas and ideals prompted by the Akbari Constitution of șulhulkul, which here may be translated as "hospitality and civility to all", a policy which was continued during the reigns of both Jahangir and Shah Jahan, as well as that of the emperor Aurangzeb, as recent scholarship has made abundantly clear (Kinra 2015). This awareness is demonstrated within Gurdas' vārs and kabbits despite the fact that there is little historical evidence of Bhai Gurdas' life.

One of the other vārs that I have in mind as having been prompted at least in part by the Bhakt-māl of Nabhadas includes vār 10. In regard to various bhakti traditions Gurdas' vār 10 conveys the well-known stories of a number of popular Bhakts/Bhagats such as Namdev (10:11), Trilochan (10:12), Dhanna (10:13), Sain/Sen (10:16), and Kabir (10:15) among others, saints who preceded Guru Nanak and many of whose hymns are found in the Adi Granth and, too, the stories of all of whom are also discovered within the Bhakt-māls. One could consider vār 10 a "mini Bhakt-māl" since such a vār on its own would, like the Bhagat Bani of the Sikh scripture, indicate a reverence for such Bhakts and lead to the conclusion that Gurdas and the Sikhs who formed his general audience would have embraced the Vaishnava bhakti traditions that so many of these Bhakts conveyed through their very lives and teachings. However, it is highly likely that in the same way that the Bhagat Bani is strategically placed in the Sikh scripture to prompt dialogue from the Sikh Gurus and highlight both similarities and differences between the teachings of the Gurus and the Bhagats so, too, is it likely that Gurdas did not mean for vār 10 to be isolated, but rather that it form a dialogic binary of sorts with the succeeding ode, vār 11 (Gill 2017, pp. 46-47).

Indeed, Guru Arjan's amanuensis reserves this next vār for the glorification of the disciples of the Gurus and in the process clearly demonstrates the independent sectarian identity of the Sikhs, an exhibition which very much forms the heart of Gurdas' Punjabi vārs and Brajbhasha kabbits (Singh 1993). As I have said elsewhere here we recognize Gurdas' understandings of the true grandeur of both the individual faithful and the congregations of said faithful, the Sikh sādhsaingat as opposed to the māl of the Bhakts: the Sikhs of the Guru, it is implied, both succeed and are greater than the Bhagats in much the same way that the number 11 both succeeds and is greater than the number 10 . The Nanak-panthi Sikhs who are named and singled out in vār 11 are, on the one hand, amazingly heroic disciples as, Gurdas tells us in paurī five of vār 11, they walk gursikhī bārìk hai khande dhār galī ati bhī $\bar{\imath}$ "the path of gursikhi, which is as narrow and sharp as the edge of a double-edged sword" (BG 11:5:1; Singh 1997, p. 177). On the other hand, they are quite ordinary too-musicians, barbers, cooks, all regular disciples of Guru Nanak and the subsequent Sikh Gurus, all of whom have achieved lofty status simply through their love, devotion, and service to the Sikh Gurus and humanity. This sets them above all others including the revered saints of the many bhakti traditions. The sangats as well as their individual components, one may also infer, are greater in the estimation of Gurdas than the sampradāys. This inference is derived in part from an earlier $v \bar{a} r$ which alludes to Gurmukhs like those referenced in vār 11; but in this case the allusion is far more general. One of these vārs is the seventh in the collection of 40 to which I shall turn in just a moment.

Certainly Bhai Gurdas, like Nabhadas and Raghavdas afterwards, does occasionally ruminate on foursomes. His take on these is often similar to those of our revered Vaishnavas. Among the iconic quartets peppered throughout the vārs and kabbits are the usual suspects, the four directions, castes, ages, Vedas, and the Dharmashastric purușāratha or four aims of life among others. What is altogether and perhaps conspicuously absent is the four sampradāys. It is highly unlikely that Gurdas was not familiar with the fourfold construct given that the structure had even been recorded in the Persian Dabistān-i Mazāhib to which we earlier alluded (Hawley 2015, p. 140). Gurdas consistently 
demonstrates his knowledge of the "world religions" that Mobad Shah effectively delineates in his Dabistān. This absence of the four sampradāys is most noticeable in the context of his seventh vār, in which Bhai Gurdas reduces all the manifold elements of existence that can be counted and are noted by numbers to the all-important number of one, collapsing in many ways everything into the singular divine which is in Sikh imaginings Ik Oañkār, the ligature with which the Adi Granth begins. The paurīs of $v \bar{a} r$ seven follow sequentially in this regard: the first glorifying the number one, the second the number two, etc., until we arrive at the 15th, which refers to those facets of Indic tradition that number between 18 to 34. In the fourth of these pauris all foursomes become dissolved not solely into the form of the One divine but rather in the person of the Gurmukh, the faithful disciple whose face is turned towards the Guru. To perhaps cancel the foursome equation in a uniquely Sikh way, Gurdas ends his vār 7:4 by ultimately referencing the sādhsangat.

\section{gurmukhi sādhi sangati nirbāṇ̄}

The one who faces the Guru achieves liberation (nirbāṇ $)$ within the community of the faithful.

(BG 7:4; Singh 1997, p. 113)

The "raised umbrella" of which Raghavdas speaks above is in Gurdas' vārs the congregation of faithful Nanak-panthis.

While what is made explicit in this vār is the collapse of all foursomes, what is implied in this final line of 7:4 is something to which we will become far more privy in vār 13: the elevation of the quintet of disciples. It is the number five on which Gurdas most effectively focuses in what is perhaps one of his most famous pronouncements which, like just about everything Gurdas writes, is shadowed by the $b \bar{a} n \bar{\imath}$ of the Sikh Gurus, likely in this case Guru Nanak's Japjī 16 (Guru Granth, p. 3). The hint of five appears in Gurdas' reference to the sādhsangat, whose core component, once again, is five Sikhs whose faces are turned towards the Guru. This idea is one that ultimately develops in the eighteenth century into the Khalsa Sikh Panj Piare, the Cherished Five, the group of Sikhs who were the first to volunteer their lives to the Tenth Guru:

\section{iku sikkh dui saing panjīn paramesaru}

One is a Sikh; two are the true congregation; and five, the Highest Lord.

$$
\text { (BG 13:19; Singh 1997, p. 225) }
$$

This stress on five is well in line with Gurdas' endeavor to chart out a terrain for Sikhs that is, put simply, unique, neither Hindu/Vaishnava nor Muslim (to make reference to the adage made popular in Guru Nanak's janam-sakhis), the former of which in the context of the Bhakt-māls lays most of its emphasis on groups of four.

Gurdas recognizes the ambivalence that our Bhakt-māl author exhibits towards the four-sampradāy model (it would be Nabhadas' eighteenth-century commentator, the Gaudiya Priyadas who would more firmly situate the idea of the four sampradāys in the popular imagination) (Hawley 2015, p. 143) and simply wished to demonstrate that essence into which all mystics wished to dissolve, the singular divine, like the many individual delectable components which ultimately merge into the Indian delicacy, paan, a common metaphor in Sikh literature which illustrates the reduction of all castes into one. It could be, too, that Gurdas having written eloquently upon the execution of Guru Arjan throughout a number of his most heartfelt vārs, particularly the fourth which originally appeared as the first, wished to disassociate himself and the Sikhs of Guru Hargobind from those forms of religio-cultural organization which were ordered under the aegis of the Mughal state-which, let us recall, had executed his beloved Guru. This would include the model of the four sampradāys, embraced as it would be some decades after the death of Gurdas by one of the most formidable proponents of the Mughal state, the Kacchvaha Rajput court. The Kacchvaha relationship to the Mughal darbar dates back to $1562 \mathrm{CE}$ when in February of that year the emperor Akbar consented to marry the eldest daughter of Raja Bharmal Kacchvaha, the woman who would later become the mother of the emperor's 
son, Salim/Jahangir. I am tempted as well to read the final line of this vār-scale collapse of all foursomes that is 7:4 as a sly rebuttal to Nabhadas who in a doh $\bar{a}$ that appears after the twenty-seventh chhappai of his Bhakt-māl tacitly refers to the very founders of the four sampradāys as guru mukhs:

\section{ramā paddhati rāmānuj rājai viṣnşvāmi tripurāri}

nimbādity sanakādikā madhukar guru mukh chāri

Ramanuja walks the path of Ramā [who is the consort of Ram, Shri], while Vishnusvami treads that of Shiva. Nimbarka's journey is along the road travelled by Sanaka and that of Madhva is the four-faced Brahma's.

Nabhadas Bhakt-māl 28 (Jha 1978, p. 10)

It is within the final portion of the doha that this understanding becomes apparent: madhukar guru mukhu chāri a phrasing which may have been interpreted by Bhai Gurdas as likening the four southern Acharyas to those whose faces are turned towards the Guru thus implying that the four teachers are guru mukhs, leaders whose faces are so turned-although this wording is likely accidental on Nabhadas' part. Even men as illustrious as our earlier guru mukhs are outshone by the true Gurmukhs, the extraordinary but simultaneously ordinary Sikhs of the Guru.

As we can see from our above foray into the vārs of Bhai Gurdas, a persistent theme which reverberates throughout his compositions is the uniqueness of the Sikhs and their Gurus, particularly Guru Nanak whose spirit for Gurdas is lodged within all of his successors. It is difficult to know just how widespread Gurdas' poetry was in the later part of the seventeenth century, but as mentioned earlier a side by side comparison with the Dabistān-i Mazāhib's Sikh narrative suggests that Mobad Shah may have been well familiar with the collection of our esteemed Sikh savant (Fenech 2017). However, widespread or not, the poetry of Gurdas was in the seventeenth and eighteenth centuries is not really the point I care to explore. What is far more significant to me is if Raghavdas was familiar with it. I think that the answer to this is yes because, from my Sikh-centered perspective, a thorough reading of the portion of Raghavdas' Bhakt-māl assessing Guru Nanak strongly suggests that Raghavdas is here in dialogue with Bhai Gurdas. This offers, I think, a novel approach to understanding Raghavdas' Guru Nanak chhappais (and, too, a new lens through which to read the poetry of Gurdas), as the few scholars who have approached the Sikh verses of Raghavdas have relied primarily on the Guru Granth Sahib in arguing their claims, perhaps (as Hawley has suggested) the Granth's apparent ubiquity as the reason why Guru Nanak is placed in the first position in the refrain of chhappai 341:2. This is, as we have seen, a very reasonable stance to take, made more so given the apparent echo of Guru Nanak's (and perhaps Guru Amar Das') śabads that we can discern in the Bhakt-māl, notes of which we catch in the reading of our Dadu-panthi saint and poet.

Positing Raghavdas' chhappais on Guru Nanak as a dialogue with Bhai Gurdas helps make sense of Raghavdas' choices in portraying Guru Nanak and both sets of the First Master's descendants, biological and spiritual, the way he does. With this in mind, it becomes quite clear that Raghavdas is also in opposition to Bhai Gurdas. Both authors of course show a similar reverence for Guru Nanak with Raghavdas likely here drawing upon some of Bhai Gurdas' descriptions of the First Master. Raghavdas it seems may be purposeful in his description of Guru Nanak as "kingly" or "sovereign" $(b h \bar{u} p)$ in the epigraph with which this lengthy paper begins, for example, a common understanding scattered throughout Gurdas' poetry. But while Bhai Gurdas' descriptions are exclusive, Raghavdas' are inclusive. And this inclusivity comes at a cost, and it is one that is paid almost exclusively by the Sikhs. Raghavdas' process of including Guru Nanak within the redemptive sphere of bhakti nevertheless limits the First Master in a number of ways-tames him, as it were-to accord with the fourfold sampradāy, and by doing so diminishes perhaps completely in the eyes of his contemporaries the uniqueness of the Sikh Panth that Bhai Gurdas so passionately champions.

It is worth repeating that such limitations are clearly noted in the way that Raghavdas contains Guru Nanak through his incorporation into the four-sampradāy model. Raghavdas, I would like to suggest, places Nanak first in this construct for the very reason that Guru Nanak was unique among all 
of the other garlanded flowers. Were the Sikhs not as distinct and widely spread throughout northern India and beyond as they likely were in the later part of the seventeenth century, it would not have really mattered in which order the four were situated (poetically, the names mentioned are all two syllables and so any of these names could technically appear in any order for Raghavdas without disturbing the meter of the line). Nanak's panth one may note was quite distinctive, with its own set of rituals and places of pilgrimage, its own principal text: all of this is noted in the poetry of Bhai Gurdas for whom, of course, Nanak's message transcends that of all others as the First Master is the both the true emperor sacha patišâh (and so Raghavdas' bhīp) and the sole teacher of the entire world, the jagat-guru (BG 24:1, 2; Singh 1997, pp. 372-73). Unlike the later Rahit literature, Bhai Gurdas' poetry is descriptive of what Sikhs hold dear rather than prescriptive.

Additionally, we may explain why Kabir follows Nanak by noting that Kabir's panth was not quite as individual; a panth, yes, but nevertheless acknowledged as it was as very much ensconced within the ambit of the sampradāys by far more writers than Raghavdas because of Kabir's very strong association with Ramanand, through whom the particular sampradāy associated with Ramanuja makes its way from southern to northern India, and this is despite the fact that-as James Hare notes in his study of Nabhadas' Bhakt-māl— “The Kabīr Panth can be understood as Vaishnava only in the broadest possible sense" (Hare 2011, p. 154). Nowhere is Nanak associated with past saints in the same ways as Kabir nor with the predecessors of either of the two other constituents in the quartet in which we find Nanak, Dadu and Jagan.

Apparently to Raghavdas Nanak was (to put it rather crudely) the most misshapen of the threaded marigolds upon the garland of saints: that a particular care beyond that of his fellow Bhakts would be granted to the illustrious Guru thus seems logical given Raghavdas aims to be as inclusive as possible, in a way which "seeks to discipline [Nanak] within the norms of the sampradāy", (Hare 2011, p. 127) and thus within the realm of Vaishnavism. Since Kabir, too, was likely a strong force with which to be reckoned in the late seventeenth century-although Kabir had already been subjected to the incorporating hand of Nabhadas-it is not surprising that he would take second place. Such positioning, therefore, aimed to bring Guru Nanak in line, in other words, with the harmony and stability that Raghavdas was attempting to draw out by draping India with his glorious garland, the Bhakt-māl. No wonder in this light that Raghavdas bookends the final chhappai of our first quartet of cantos with both Nanak and Dadu and not Kabir and/or Jagan: the most prominent of the Bhakts as it were and Raghavdas' own master. Not only does this chhappai further connect the two to the earlier mahants of the southern sampradāys but, with Dadu's taming presence succeeding Nanak, it was another way to help iron out the distinctiveness of the Sikhs perhaps to "Vaishnavise" the Sikhs as Hawley notes but to most certainly "Dadu-ise" Guru Nanak and thus by extension the Sikhs. One may indeed go so far as to argue that Raghavdas is attempting to rescue Baba Nanak from, in one sense, the less universalistic understandings of Gurdas.

It is with this in mind that we should approach one of the most intriguing segments of the Bhakt-māl: Guru Nanak's biological lineage. I single this one out since the list of successive Gurus noted by Raghavdas in the subsequent chhappai (348) is very much in line with that of which we read in Gurdas' vārs, especially vār 24 which notes the line of succession from the First to the Sixth Guru, drawing in part upon both Bhai Gurdas' own experiences with the Sikh Gurus as well as the famous hymn in vār rāmkali by the musicians Satta and Balwand in the Guru Granth Sahib, in which the idea of the similarity of all the Sikh Gurus as Nanak is made clear (BG 24; Guru Granth, p. 966). Even within Persian Sikh literature this lineage is elaborated, most notably within the Persian Joti Bigās (The Divine Light Effulgent) of Guru Gobind Singh's most prominent court poet, Bhai Nand Lal Goya which appears a few decades after Raghavdas' Bhakt-māl (Singh 1963, pp. 159-69). Of course, Raghavdas as we have noted takes the lineage two Gurus further than Bhai Gurdas for obvious reasons, to Guru Hari Krishan. The description of Nanak's children offered by Raghavdas in chhappai 347 is provided below in full: 
śrī nānak gur taim ūpaj ubhai bhrāt hari bhakt ye

lakṣmīdās grah bās tās ke sāhib-zādā

śrī chand kai vairāg udāsī jā parasāà

śrī chand kai chatur siṣ chaum disā pujāye

uttar purab dakhin pachhim asthān banāye

alamast phul sāhib bhagat bhagavant hasan bāllū priye

śrī nānak gur taị ūpaj ubhai bhrāt hari bhakt ye

From Sri Nanak Guru had been born two sons, both of whom were great Bhakts of Hari.

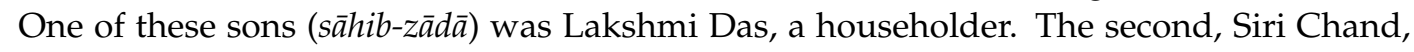
was through the grace of God a renouncer (vairāg) who travelled in a detached manner $(u d \bar{a} s \bar{\imath})$. Siri Chand had four disciples (siṣ) who went out to the four directions and caused many to worship the divine. In the north, west, south, and east they established houses of veneration (asthāimn). Almast, Phul, and Sahib were bhagats who along with Hasna Balu, were immersed in divine love. From Sri Nanak Guru had been born two sons, both of whom were great Bhakts of Hari.

Bhakt-māl 347 (Nahta 1965, p. 176)

Once again, the two sons of Guru Nanak are nicely counterpoised along the lines of the celibate ascetic/householder divide we see in Mobad Shah's work. However, rather than spend further time on Lakshmi Das who, based on this binary, would have aligned better with the Sikh tradition as advocated by Bhai Gurdas, a tradition in which the householder living truthfully could accumulate the knowledge that leads to liberation, he focusses on Siri Chand as vairāgi and the community which is inaugurated by him, the Udasis, a term he notes as we can see, in all of its ambiguity as both wanderer and wanderings. As we see, the bulk of this chhappai (four of six lines) is devoted to this ascetic dimension of the Sikh tradition. Perhaps Raghavdas may have been able to easily encompass the Udasi lineages in his scheme since Sikh tradition, too, remembers the four as having established four dhūāns or "fireplaces" all of which are named after these appointees. Surprisingly, or perhaps not, Raghavdas fails to include the six sub-classifications of the Udasi tradition.

It seems unlikely to me that Sikhs whose opinions about their tradition were aligned with those of Bhai Gurdas would not have noticed the use of the word siṣ (sikkh) to describe these Udasi mahants. However, while Gurdas and like-minded pious Sikhs may have ignored and even condemned the Udasis, regular Sikhs most likely would have not. As noted by other scholars both Nabhadas and Raghavdas likely pay more attention to the quotidian in their poetic accounts than what was discovered in texts despite the fact that texts still retained significance for our bhakti authors (Hare 2011). Here, in this light, one notices that Raghavdas' information does not perfectly tally with what we discover in Sikh records as, in the latter, these four last disciples who establish dhīanns throughout India are the devotees not of Siri Chand but rather of the son of Guru Hargobind, Baba Gurditta, who, according to Sikh tradition, is inducted into the Udasi order by Siri Chand himself (Nara 1975). It is also worth noting that Sikh tradition claims that the four Udasi mahants assigned by Gurditta were named Almast, Phul, Gond (or Gondā) and Hasan Balu while Raghavdas' list has Sahib in the place of Gond.

This could suggest of course that the Udasi Sikhs who Raghavdas is here referencing were a considerable presence within the Sikh Panth by the time Raghavdas was preparing his text, which likely seems the case given the more "ascetic theme" in the janam-sakhis about which Hew McLeod has written (McLeod 1980a, pp. 57-58). This was a prestige derived in part from their associations with the Sikh Guru. Such a reputation may be discerned, furthermore, from the sources within the Maratha polity. A detailed account from the city of Burhanpur dating to the 1760s, for example, notes the grant of "monthly wages" to a Nānak-putrā or an Udasi sadhu (Gordon 2000, p. 329). Now this report is removed from Raghavdas' text by almost a century, but tradition claims that the Udasis were a presence in south India quite early in the history of the Sikh tradition, a tradition which suggests that 
Udasis were seen as representatives of the Sikh tradition, at least in the south, a belief that appears to account for Raghavdas' curious reference to Guru Nanak's northern origin in the opening and closing lines of chhappai 345 above. $^{5}$

The praise of the Udasis, their apparent southern stature notwithstanding, may be situated in the context of Raghavdas's dialogue with Bhai Gurdas, the latter of who has very little to say about the sons of Guru Nanak. Gurdas reserves his comments to one solitary line about Siri Chand, discovered in 33rd paurī of vār 26:

\section{bāl jatī hai sirichandu bābāṇa dehurā banāiā}

Siri Chand who was ascetically inclined since childhood erected a monument to honour his elder.

$$
\text { (BG 26:33:1; Singh 1997, p. 425) }
$$

This statement may seem innocuous on its own but, situated as it is within this particular pauri $\overline{\text {, the }}$ meaning and the intent becomes clear as we read on. The theme around which Gurdas constructs this particular pauri $\bar{i}$ regards the person who is enmeshed by māi $i \bar{a}$ (delusion) and self-centeredness (haumai), and prompted by these nefarious forces accords to oneself the greatness that is guruship. All of the descendants of the legitimate Sikh Gurus mentioned in the pauri are likened to the arch nemesis of the Sikhs in Gurdas' poetry, the minnās. In this light, therefore, all that Siri Chand became was the Other against which Gurdas constructed his understanding of both the Gurmukh and the type of Sikhism that such Gurmukhs embraced and embodied, a tradition that categorically rejected asceticism. Gurdas ends the paurī by noting that people such as Siri Chand are chandan vasu na vās bohāiā, "like bamboo, which despite its proximity to sweet-smelling sandalwood nevertheless remains malodorous" (BG 26:33:7; Singh 1997, p. 425).

\section{Afterword}

As one can easily see throughout this paper, I have relied quite heavily on the work of bhakti scholar Jack Hawley, especially his focus on the four sampradāys in situating my discussion of Raghavdas and Guru Nanak. Hawley's work on the sampradāys and Raghavdas has been particularly helpful in exposing this niche in Sikh studies to me-that is, early bhakti attitudes towards the Sikh Gurus. The present paper is offered as an expansion of Hawley's work, though with a focus on the Sikh tradition that is clearly peripheral in Hawley's essays.

This type of collaboration if you will is very good for us in Sikh studies, for it has only been within the last two decades or so that scholars of Sikh history and tradition have begun to engage those Indologists whose work lies predominantly within different though related Indological fields in the hope of understanding the development of both Sikhism and the traditions which were its contemporaries. The goals between we scholars (of Sikhism and of bhakti traditions) are shared but, in so many instances, our perspectives differ. This was made quite explicit to me as I read Professor Hawley's very astute claim that

The Sikhs developed an intricate system of anthological practice that made it possible to locate the compositions of their own gurus within a wider range of songs ascribed to others.

(Hawley 2015, p. 126)

For me, the phrasing of this claim should in fact be altered given the situationality of the Bhagat Bani to which Hawley refers in this particular quotation. Thus, I would argue that the Sikhs develop a system which allowed the songs of non-Sikhs to be located within the compositions (that is the ideology) of the Gurus. What Professor Hawley's comment fails to note explicitly is that the Bhakt hymns 
included in the Adi Granth were incorporated because some agreed with the ideas of the Sikh Gurus while others, more importantly, did not. Those that did not agree are immediately followed by hymns of the Gurus, the aims of which are placing the Bhagats back on course, so to speak, and thus allowing Sikhi to stand in stark contrast to the tradition(s) espoused by the Bhakts/Bhagats. The difference between both my view and that of Professor Hawley is, once again, one of perspective.

This difference, at the same time, also gives rise to the issue of taming and containing. Here is where Raghavdas comes into play. Raghavdas notes enough of Guru Nanak in his Bhakt-māl to ensure that the First Master is fairly ensconced within the model of the four sampradāys. Put simply, Raghavdas contains the revered Guru and his following within his chhappais and goes on his merry bhakti way, turning immediately afterwards to the primary exponent of $n$ rgun bhakti, Kabir without paying the Guru and the Sikhs a second thought.

In many ways, this examination of mine, linked as it is to containment and limitations, brought me again and again to descriptions of the thought of Guru Nanak which generally note that Nanak's doctrine has been, in large part, refracted through the lenses of modern commentators and scholars to form the systematic theology to which we today attach Nanak's name, a theology that has been influenced (inevitably) by "modernist and secular scholarship." There is merit to this claim, but it is one which must nevertheless be tempered. We cannot ignore the modern in the construction of the construct that is Guru Nanak, but such statements we make as scholars are, let us be clear, as confining of the First Master as are those of Raghavdas.

Funding: This research received no external funding.

Acknowledgments: I would like to thank Pashaura Singh for allowing me to deliver an earlier and much longer version of this essay at the University of California Riverside Sikh Studies conference commemorating the 550th anniversary of Guru Nanak's birth in May 2019. I dedicate this paper to him.

Conflicts of Interest: The author declares no conflict of interest.

\section{References}

Alam, Muzaffar. 1986. The Crisis of Empire in Mughal North India: Awadh and the Punjab 1707-1748. New Delhi: Oxford University Press.

Ali, Maulawi Agha Ahmad, ed. 1871. The Maásir I 'Álamgírí of Muhammad Sáqi Musta'idd Khán. Calcutta: Baptist Mission Press.

Bahuguna, Rameshwar Prasad. 2013. 'Religion and State in Eighteenth Century Rajasthan: Sawai Jai Singh and "Reformed" Vaishnavism'. Paper presented at Indian History Congress, Odisha, India, December 28-30; vol. 74, pp. 353-62.

Bangha, Imre. 2015. A Curious King, a Psychic Leper, and the Workings of Karma: Bajid's Entertaining Narratives. In Tellings and Texts: Music, Literature and Performance in North India. Edited by Francesca Orsini and Katherine Butler Schofield. Cambridge: Open Book Publishers, pp. 359-81.

Bedi, Tarlochan Singh, ed. 1994. Sikkhān dī Bhagatmālā. Patiala: Punjabi University Press.

Behl, Aditya. 2010. Pages from the Book of Religions: Comparing Self and Other in Mughal India. In Notes from a Mandala Essays in the History of Indian Religions in Honor of Wendy Doniger. Edited by Laurie L. Patton and David L. Haberman. Newark: University of Delaware Press, pp. 113-49.

Translated and Edited by Heinrichand Blochmann. 1997, The A-in-Akbari. Delhi: Low Priced Publications, vols. 2-3.

Burchett, Patton E. 2012. Bhakti Religion and Tantric Magic in Mughal India: Kacchvāhās, Rāmānandīs, and Nāths, circa 1500-1750. Ph.D. dissertation, Columbia University, New York, NY, USA.

Callewaert, Winand M. 1987. Dadu and the Dadupanth: The sources. In The Sants: Studies a Devotional Tradition of India. Edited by W. H. McLeod and Karine Schomer. Delhi: Motilal Banarsidass.

Callewaert, Winand. 1994. Bhaktmāls and Parcā̄s in Rajasthan. In According to Tradition: Hagiographical Writing in India. Edited by Winand Callewaert and Rupert Snell. Weisbaden: Harrassowitz Verlage, pp. 87-99. 
Chatterji, Sunil Kumar. 1979. A Verse by Guru Nanak in the Ādi Granth Quoted by the Emperor Aurangzeb Alamgir. In Select Papers Angla-Nibhanda-Chayana II. Edited by Suni Kumar Chatterji. New Delhi: People's Publishing House.

Chopra, Radhika. 2018. Amritsar 1984: A City Remembers. Lanham: Lexington Books.

Dhavan, Purnima. 2011. When Sparrow Became Hawks: The Making of the Sikh Warrior Tradition, 1699-1799. New York: Oxford University Press.

Esfandyar, Mobad Kaykhusrau. 1983. Dabistān-i Mazāhib I. Edited by Rahim Rizazadah-i Malik. Tehran: Kitabkhanah-i Tahuri. First published 1362.

Fenech, Louis E. 2008. The Darbar of the Sikh Gurus: The Court of God in the World of Men. New Delhi: Oxford University Press.

Fenech, Louis E. 2017. Review of R.S. Gill, Drinking from Love's Cup: Surrender and Sacrifice in the Vārs of Bhai Gurdas Bhalla. Sikh Formations 13: 225-33.

Gill, Rahuldeep Singh. 2017. Drinking from Love's Cup: Surrender and Sacrifice in the Vārs of Bhai Gurdas Bhalla. New York: Oxford University Press.

Gordon, Stewart. 2000. Maratha Patronage of Muslim Institutions in Burhanpur and Khandesh. In Beyond Turk and Hindu: Rethinking Religious Identities in Islamicate South Asia. Edited by David Gilmartin and Bruce B. Lawrence. Gainesville: University Press of Florida, pp. 327-38.

Goswamy, B. N., and J. S. Grewal. 1969. The Mughal and Sikh Rulers and the Vaishnavas of Pindori: A Historical Interpretation of 52 Persian Documents. Simla: Indian Institute of Advanced Study.

Jagtar Singh Grewal, and Irfan Habib, transs. 2001, Sikh History from Persian Sources. New Delhi: Tulika.

Grewal, Jagtar Singh. 1979. Guru Nanak in History, 2nd ed. Chandigarh: Publication Bureau Panjab University.

Grewal, Jagtar Singh. 2007. Sikh Ideology, Polity, and Social Order: From Guru Nanak to Maharaja Ranjit Singh. New Delhi: Manohar.

Hare, James P. 2011. Garland of Devotees: Nābhādās' Bhaktmāl and Modern Hinduism. Ph.D. dissertation, Columbia University, New York, NY, USA.

Hawley, John Stratton. 2005. The Nirguṇ/Sagun Distinction. In His Three Bhakti Voices. New Delhi: Oxford University Press, pp. 70-86.

Hawley, John Stratton. 2013. The Four Sampradayas—and Other Foursomes. In Bhakti Beyond the Forest: Current Research on Early Modern Literatures in North India, 2003-2009. Edited by Imre Bangha. Delhi: Manohar, pp. 21-50.

Hawley, John Stratton. 2015. A Storm of Songs: India and the Idea of the Bhakti Movement. Cambridge: Harvard University Press.

Horstmann, Monika. 2000. The Flow of Grace: Food and Feast in the Hagiography and History of the Dādūpanth. Zeitschrift der Deutschen Morgenländischen Gesellschaft 150: 2.

Horstmann, Monika. 2015. The Example in Dadupanthi Homiletics. In Tellings and Texts: Music, Literature and Performance in North India. Edited by Francesca Orsini and Katherine Butler Schofield. London: Open Book Publishers, pp. 31-60.

Jha, Narendra, ed. 1978. Bhaktmāl: Pāthānuśílan evam Vivechan. Patna: Anupam Prakāśan.

Khan, Dominique-Sila. 2004. Crossing the Threshold: Understanding Religious Identities in South Asia. London: Taurus Books.

Kinra, Rajiv. 2015. Writing Self, Writing Empire: Chandar Bhan Brahman and the Cultural World of the Indo-Persian State Secretary. Oakland: University of California Press.

Macauliffe, Max Arthur. 1990. The Sikh Religion: Its Gurus, Sacred Writings, and Authors V. New Delhi: Low Price Publications.

McLeod, William H. 1968. Gurū Nānak and the Sikh Religion. Oxford: Clarendon Press.

McLeod, William H. 1975. The Evolution of the Sikh Community: Five Essays. Oxford: Clarendon Press.

McLeod, William H. 1978. On the Word Panth: A Problem of Definition and Terminology. Contributions To Indian Sociology 12: 287-95. [CrossRef]

McLeod, William H. 1980a. Early Sikh Tradition: A Study of the Janam-sākhīs. Oxford: Clarendon Press.

Translated and Edited by William H. McLeod. 1980b, The B40 Janam-sakhi. Amritsar: Guru Nanak Dev University.

Nahta, Agarchand, ed. 1965. Rāghavdās kṛt Bhakt-māl (Chaturdās kṛt Ṭîkā Sahit). Jodhpur: The Director Rajasthan Oriental Research Institute.

Nara, Ishar Singh. 1975. Itihās Bābā Sirī Chand j̄̄ Sāhib ate Udāsī Sampradāi. Amritsar: Ishar Singh Nara. 
Oberoi, Harjot. 1994. The Construction of Religious Boundaries: Culture, Identity and Diversity in the Sikh Tradition. New Delhi: Oxford University Press.

Padam, Piara Singh, ed. 2003. Gurū kīān Sākhīān kṛt: Bhā̄ Svarūp Singh Kauśiś, 5th ed. Amritsar: Singh Brothers.

Pinch, Vijay. 1999. History, Devotion and the Search for Nabhadas of Galta. In Invoking the Past: The Uses of History in South Asia. Edited by Daud Ali. New Delhi: Oxford University Press.

Pinch, William R. 2006. Warrior Ascetics and Indian Empires. Cambridge: Cambridge University Press.

Pradhan, Khazan Singh, ed. 1986. Srī Japu Sāhib Sațīk Garab Gañjanī Ṭīkā Rachit Kavī Chūrāmaṇi Bhāı̄ Santokh Singh jī. Amritsar: Bhai Javahar Singh Kirpal Singh and Co.

Sharma, Sunil. 2017. Mughal Arcadia: Persian Literature in an Indian Court. Cambridge and London: Harvard University Press.

Singh, Ganda, ed. 1949. Maākhizz-i Tavārīkh-i Sikhān jild avval: Ahd-i Gurū Sāhibān. Amritsar: Sikh History Society. Singh, Ganda, ed. 1963. Kulliyāt-i Bhā̄ Nand Lal Goyā. Malaka: Sikh Sangat.

Singh, Ganda, ed. 1974. Early European Accounts of the Sikhs and History of Origin and Progress of the Sikhs. New Delhi: Today \& Tomorrow's Printers \& Publishers.

Singh, Ganda, ed. 1985. Hukamnāme: Gurū Sāhibān, Mātā Sāhibān, Bandā Siñgh ate Khālsā jū de. Patiala: Panjabi University Publication Bureau.

Singh, Ganda. 1940. Nānak Panthis or The Sikhs and Sikhism of the 17th Century (Translated from Muhsin Fani's Dabistân-i Mazâhib). The Journal of Indian History 19: 195-219.

Singh, Kharak, and Gurtej Singh, eds. 1995. Episodes from Lives of the Gurus_Parchian Sewadas_English Translation and Commentary. Chandigarh: Institute of Sikh Studies.

Singh, Onkar, ed. 1993. Kabbit Savaiye Bhā̄ Gurdās: Pāthh, Tuk-tatkarā, Anukramaṇikā ate Koś. Patiala: Punjabi University Publication Bureau.

Singh, Pashaura. 2000. The Guru Granth Sahib: Canon, Meaning and Authority. New Delhi: Oxford University Press.

Singh, Pashaura. 2003. The Bhagats of the Guru Granth Sahib: Sikh Self-Definition and the Bhagat Bani. New Delhi: Oxford University Press.

Singh, Pashaura. 2006. Life and Work of Guru Arjan: History, Memory, and Biography in the Sikh Tradition. New Delhi: Oxford University Press.

Singh, Randhir, ed. 1977. Bābāṇ̄i Pìrhī Chalī: Gur-Praṇālīān. Amritsar: Sikh Itihas Research Board.

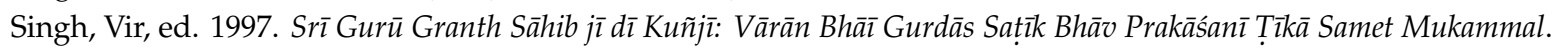
New Delhi: Bhai Vir Singh Sahit Sadan.

Translated and Edited by Wheelerand Thackston. 1999, The Jahangirnama: Memoirs of Jahangir, Emperor of India. New York: Oxford University Press.

Truschke, Audrey. 2016. Cultures of Encounters: Sanskrit at the Mughal Court. New York: Columbia University Press.

Williams, Tyler W. 2014. Sacred Sounds to Sacred Books: A History of Writing in Hindi. Ph.D. thesis, Columbia University, New York, NY, USA.

(C) 2020 by the author. Licensee MDPI, Basel, Switzerland. This article is an open access article distributed under the terms and conditions of the Creative Commons Attribution (CC BY) license (http://creativecommons.org/licenses/by/4.0/). 